
internationales

vol. $30-n^{\circ} 1 \mid 2014$

Mineurs en migration : enjeux juridiques, politiques et sociaux

\title{
Moving Children: Lacunae in Contemporary Human Rights Protections for Migrant Children and Adolescents
}

Mineurs en migration: les lacunes des droits de l'homme contemporains en

matière de protection des enfants et adolescents migrants

Menores migrantes: las deficiencias de los derechos humanos contemporáneos

con respecto a la protección de los niños y adolescentes migrantes

Jacqueline Bhabha

\section{(2) OpenEdition}

\section{Journals}

Electronic version

URL: https://journals.openedition.org/remi/6747

DOI: $10.4000 /$ remi.6747

ISSN: $1777-5418$

\section{Publisher}

Université de Poitiers

\section{Printed version}

Date of publication: 1 March 2014

Number of pages: $35-57$

ISBN: 979-10-90426-21-4

ISSN: 0765-0752

\section{Electronic reference}

Jacqueline Bhabha, "Moving Children: Lacunae in Contemporary Human Rights Protections for Migrant Children and Adolescents", Revue européenne des migrations internationales [Online], vol. 30 $\mathrm{n}^{\circ} 1$ | 2014, Online since 01 March 2017, connection on 16 April 2022. URL: http:// journals.openedition.org/remi/6747 ; DOl: https://doi.org/10.4000/remi.6747 


\section{Moving Children: \\ Lacunae in Contemporary Human Rights Protections for Migrant Children and Adolescents}

\section{Jacqueline Bhabha'}

\section{Introduction}

The first four months of 2011 will go down in history as "the Arab Spring", a moment when the unmet aspirations of the next generation hit global headlines. Alongside the inspiring images of young people taking to the streets to overthrow entrenched dictators and demand their freedom in Tunis, Cairo, Benghazi, Tripoli, Sana'a and Homs ${ }^{2}$ appeared reports noting the region's unique demographic gift $(60 \%$ of its population is under thirty) and simultaneous demographic risk (25\% of under-thirty-five-year-olds are unemployed) ${ }^{3}$. Complementing both were disturbing news stories of children and adolescents ${ }^{4}$ squeezed with adults into precarious boats fleeing violence, chaos and unemployment at home to search for a future across the sea. Young people were and are on the move, taking their life into their own hands, at whatever cost. The following vignette is typical of many: on August 1, 2011, "[t]he Italian Coast Guard found the bodies of twenty-five young men in the hold of a boat crowded with migrants that was intercepted... en route from Libya". Among the

\footnotetext{
1 Professor of the Practice of Health and Human Rights, Harvard University, John F. Kennedy School of Government, Mailbox 14, 79 JFK Street, Cambridge, MA 02138, USA; jacqueline_bhabha@harvard.edu

2 This region is commonly referred to as MENA - Middle East and North Africa.

3 International Finance Corporation (2011) Education for Employment: Realizing Arab Youth Potential, Washington DC, IFC, $107 \mathrm{p}$.

4 The terms child, adolescent, youth and young person overlap but differ. Only the first is defined in international law: "a person under the age of 18 [...]" (Convention on the Rights of the Child, Art. 1). The other terms lack an agreed universally applicable definition; however, some consensus exists about their common usage. UNICEF, together with its partners UNFPA, WHO and UNAIDS, defines an adolescent as a person between ten and nineteen; the UN defines youth as persons between fifteen and twenty-four. No official definition of young person exists. This chapter will use the terms interchangeably. Most unaccompanied child migrants are in fact adolescents; and many reports on independent youth migrants do not specify their exact age.
} 
survivors were twenty-one children ${ }^{5}$. Migrant tragedies, though rampant in the spring of 2011, persist: most notably, on Friday, October 3, 2013, a flimsy overcrowded boat venturing to Italy's Lampedusa capsized. The shipwreck claimed at least 367 lives, including children ${ }^{6}$. The Arab exodus illustrates the reality of youthful mixed migration across the Mediterranean Sea today, what some experts refer to as a "asylum-migration nexus", or a blurring of legal categories within contemporary migration (Betts, 2006: 652-676; UNHCR, 10-Point Plan). This varied and multifaceted flow includes asylum seekers, exploited unaccompanied children, job seekers, education or opportunity seekers, and adolescents seeking family reunion with previously migrated parents; all of them, in one way or another, young people on the move for a better life. The exodus also shone a public spotlight on a phenomenon recognized by experts for some years - the growing presence of children and adolescents within contemporary migration.

For many involved in the Arab exodus, their courageous journey ended badly ${ }^{7}$. Sympathy with liberation movements and concern with youth unemployment abroad do not translate into a hero's welcome for brave young migrants. Disturbing stories abound. On June 22, 2011, an Egyptian adolescent drowned at sea trying to swim to the Sicilian shore as the boat's propeller hit him; on the same day, the humanitarian organization Terre des Hommes reported that 260 migrant children had been detained for over a month on the Southern Italian island of Lampedusa at a former NATO base with a maximum capacity of $180^{8}$. The conditions at this base turned child detention center had caused concern for some time. A few months before the Terre des Hommes report was issued, during a visit to the same base, Amnesty International complained of inadequate child supervision, and received reports of bullying, severe anxiety and other indications of distress from the detained minors ${ }^{9}$. Children fleeing conflict and destitution in North Africa and hoping for a better life had ended up in painful detention in Europe.

The growing presence of young migrants in these dramatic journeys and their traumatic migration experiences are symptomatic of a new demographic phenomenon. As the European Commission noted in its 2010 Action Plan on Unaccompanied Minors, "The challenge of unaccompanied minors is growing: a considerable number of third-country nationals or stateless persons below the age of eighteen arrive on EU territory unaccompanied by a responsible adult, or are left unaccompanied after they have entered EU territory". Over 7,000 unac-

\footnotetext{
5 Pianigiani Gaia (2011) 25 Migrants Found Dead in Boat Near Italy Coast, New York Times, Aug. 1.

6 Stevis Matina and Ball Deborah (2013) Behind Lampedusa Shipwreck: A Journey of Perils and Profits. Vast and Lucrative Migrant-Smuggling Business Defies Europe's Crackdown Efforts, The Wall Street Journal, Dec. 19.

7 According to the Parliamentary Assembly of the Council of Europe (PACE), 2011 was "the deadliest year for boat people" crossing the Mediterranean, with a record number of fatalities (PICUM Quarterly Newsletter, Aug.-Nov. 2, 2011). Leanne Weber reports, on the basis of an exhaustive compilation of NGO records, that between 1993 and 2012, 16,136 deaths directly related to European border control, have occurred. 1,500 refugees and migrants drowned in the Mediterranean en route to Europe in 2011 alone, turning the Mediterranean into a "nautical graveyard" (Weber and Pickering, 2011).

8 PICUM Bulletin, July 4, 2011.

9 Amnesty International (2011) Italy: Amnesty International findings and recommendations to the Italian authorities following the research visit to Lampedusa and Mineo, 6 p.
} 
companied children arrived in Italy in the first quarter of $2009^{10}$. Although some Member States experience this far more than others, all are affected ${ }^{11}$. The same document noted a $40.6 \%$ increase in the number of minor asylum applications lodged in the twenty-two EU Member States of the European Migration Network in 2008, compared to the previous year ${ }^{12}$. This phenomenon does not only affect Europe. $13 \%$ of today's global mixed migration flow is made up of children, adolescents and youth under twenty ${ }^{13}$, many of whom travel alone to advance their interests despite sizeable physical dangers, institutional challenges and ambivalent political response (Yaqub, 2009). A global commitment to protect children from adversity is subordinated, in the policy limelight, to an international determination to punish and deter irregular migration. Young migrants are high priorities for both.

\section{The Right to Have Rights}

Whether they are asylum seekers, independent migrants, trafficked youth or children smuggled for family reunion purposes, or whether their status is unclear (between categories or within several), all young migrants need protection and assistance of one sort or another - safe accommodation, and protection from exploitation, from the risks of criminalization, from deprivation of food and medical care at a minimum. As Save the Children Brussels noted "The rights and needs of these children to assistance arise often before the appropriate protection route or long term solution options are known"14. Devising mechanisms to satisfactorily engage this need for a "horizontal" approach ${ }^{15}$ to adolescent migrant protection independent of the particular categorical silo which encompasses the child's legal status is an unfinished task. It entails returning to some very basic, unchallenged human rights principles: non discrimination, a primary focus on best interest, the right to life and to respect for one's private life, and the right to have one's voice heard.

These rights are interdependent. But policy makers and implementers in government departments charged with protecting these rights tend to be limited by discrete departmental mandates. They have specific tasks to execute and they are accountable along vertical lines of reporting that militate against flexibility, interdepartmental collaboration or the creative exercise of discretion. Ensuring a streamlined immigration process at the border, securing the hand over of minors to the appropriate authorities, efficiently staffing the decision making system, resourcing the detention and removal operations, responding to the political clamour for effective immigration control and timely through put of migrants are discrete functions. They do not sit easily with an integrated

10 Save the Children (2009) General Recommendations for EU Action in relation to Unaccompanied and Separated Children of Third Country Origin, Sep. 15, 2 p.

11 European Commission (2010) Action Plan 2010-2014, Brussels, p. 2.

12 lbid.

13 UNICEF (2010) Children, Adolescents and Migration. Filling the Evidence Gap, June, pp. 3-4.

14 Save the Children (2009) General Recommendations for EU Action in relation to Unaccompanied and Separated Children of Third Country Origin, Sep. 15, 2 p.

15 lbid. 
engagement with a child's experience of the complex demands of a protracted migration situation. Official functions do not map onto an obligation to evidence concern for the fundamental human rights principles that generate continuity of child care, protection from abuse, stigma or physical hardship or a sense of security and wellbeing.

Adolescent migrants present a complex package of needs and rights. Like other children, they are, as a matter of law, entitled to have their best interests taken into account in all decisions affecting them, without discrimination based on their race, nationality or other status. Like other children, they require safe haven, access to adequate food, water, accommodation, shelter, medical treatment and education, a complex and multifaceted package of entitlements that span multiple departmental responsibilities. But that is not all. Adolescent migrants are also entitled to be heard in relation to their interests, to have their views and opinions solicited just as their non-migrant counterparts are. The more mature the minor, the more weight needs to be accorded to his or her views on matters concerning relevant decision-making. This means that policy makers and implementers alike have a responsibility to craft and apply procedures that are holistic, flexible and based on careful judgment. These decisionmaking characteristics require training and leadership. But they also presuppose innovation, consultation and monitoring to ensure that official responses add up to a rights respecting engagement with children whilst they are in State custody.

At the same time as the North African migrant adolescents headed for Lampedusa were leaving home to seek opportunities across the Mediterranean, world leaders were gathering to discuss global migration. On May 19, 2011, the United Nations General Assembly held a discussion on international migration and development for the very first time. Secretary General Ban Ki-Moon opened the proceedings by calling on Member States to "harness the unstoppable force of migration for the greater good"16. He cited statistics showing "that the economic contribution of migrant workers far outweighs any costs"17. While the setting for the Secretary General's comments was new, his two key points were not. Despite enormous investments in policing, intelligence and legal provisions over many decades, there is resigned acknowledgement, across the political spectrum that effective border control continues to elude target destination States ${ }^{18}$. As the former head of the US Department of Homeland Security under the Bush Administration, Michael Chertoff, conceded: “Enforcement alone is not

16 Rawat Dinesh Singh (2011) UN General Assembly Debates International Migration and Development, $A B C$ Live, May 20.

17 Ibid.

18There are 11.2 million undocumented migrants living in the United States and in 2011, the US government spent over \$17 million USD on immigration enforcement activities (figure includes the budgets of US Customs and Border Protection and US Immigration and Customs Enforcement). See Passel Jeffrey S. and Cohn D'Vera (2011) Unauthorized Immigrant Population: National and State Trends 2010, Washington DC, Pew Hispanic Center, p. 1; and US Department of Homeland Security (2011) FY 2011: Budget in Brief, Washington DC, Homeland Security, p. 17. In Europe, approximately 570,000 irregular migrants were apprehended in 2009. The European Agency for the Management of Operational Cooperation at the External Borders (FRONTEX) budgeted $€ 88,410,000$ $(\$ 113,845,557$ US) for immigration enforcement activities in 2011. See European Commission Home Agency, [online]. URL: http://ec.europa.eu/dgs/home-affairs/index en.htm; FRONTEX, Budget 2011, [online]. URL: http://frontex.europa.eu/ 
enough to address our immigration challenges... [As long as the] opportunity for higher wages and a better life draws people across the border illegally or encourages them to remain here illegally [preventing migration will be difficult]" ${ }^{19}$. This is not surprising as robust engagement with policies to address rights needs in the countries of origin of young migrants, an essential complementary development, has been lacking. And, grudgingly or defensively, the same States have for some time had to admit, as Secretary General Ban Ki-Moon noted, that migrant workers, especially young, unattached and healthy ones, are likelier to add far more to their economies than they cost ${ }^{20}$.

The Secretary General's call for positive approaches to migration is welcome. States have generally failed to demonstrate their intention or ability to harness the force of migration for the greater good. EU Member States have even turned their back on countries with which they have had long standing historical links and instituted blanket return policies: already in 2009 Italy adopted a policy of returning migrants within international waters to Libya, a former colony and close trading partner, without any prior evaluation of their protection needs ${ }^{21}$.

Nowhere is the impact of this failure to harness migration flows for positive outcomes clearer than in the case of young migrants, adolescents on the move to secure a better future for themselves and their families. With ambition, energy and years ahead of them, this cohort has an untapped capacity for contributing particularly to rapidly ageing societies. The Middle East and North Africa (MENA) region does not have a monopoly on such migrations. No major continent is unaffected. Tens of thousands of child migrants have crossed the border between Mexico and the United States for decades fleeing conflict, abuse, violence and poverty in search of better opportunities. Though an estimated 43,000 are removed back home each year ${ }^{22}$, it is probable that a far larger number remain. Europe has also witnessed a huge movement of child migrants travelling from third countries into the European Union ${ }^{23}$; and in Africa, Latin America and Australia too many thousands of adolescents are on the move each year. As a matter of international and domestic law, but also of social justice and political rationality, this population of young people including those who are unaccom-

19 Statement for the Record, The Honorable Michael Chertoff, Secretary, United States Department of Homeland Security Before the United States House of Representatives Committee on Homeland Security, July 17, 2008, cited in Kanstroom, 2012: 98.

20 UN General Assembly (2006) International Migration and Development. Report of the Secretary-General, 18 May, A/60/871, pp. 44-45. See also Home Office and DWP (2007) The Economic and Fiscal Impact of Immigration, London, HMSO, CM 7237, 44 p.

21 Human Rights Watch (2009) Pushed Back, Pushed Around: Italy's Forced Return of Boat Migrants and Asylum Seekers, Libya's Mistreatment of Migrants and Asylum Seekers, New York, Human Rights Watch, p. 1.

22 Center for Public Policy Priorities (2008) A Child Alone and Without Papers - A report on the return and repatriation of unaccompanied undocumented children by the United States, Austin, CPPP, p. 7.

23 In 2010, there were an estimated 7.5 million child migrants in Europe, many from Eastern Europe and North Africa. See UN DESA, Trends in International Migrant Stock: Migrants by Age and Sex, UN Database, POP/DB/MIG/Stock/Rev.2011. See also FRONTEX (2011) Annual Risk Analysis 2011, pp. 14-23. It is worth noting that there are no reliable figures on the number of undocumented child migrants in Europe. In many countries, the only source of demographic information may come from border apprehension data, which likely underreports the phenomenon. Additionally, there are significant variations in quality and methods of data collection across the countries. 
panied are entitled to a much more vigorous realization of what Hannah Arendt called the 'right to have rights'.

With great foresight, this German Jewish refugee political philosopher recognized a fundamental human rights challenge of our age: supposedly "inalienable rights are unenforceable for individuals who lack [...] their own government". Though Arendt did not envisage the cosmopolitan collectivity that constitutes the national population in many of the States to which child migrants travel today, her insight is no less relevant: multicultural polities today generate de facto statelessness through border control regimes rather than race laws (Butler and Spivak, 2007: 62-66).

The international community acknowledged Arendt's insight about the perils of this situation by enshrining a comprehensive body of principles - human rights norms - designed to reduce individuals' dependence on "their own government" for protection of their basic rights. Migrant adolescents, like everyone else, are covered by these generic principles first articulated in the 1948 Universal Declaration of Human Rights and subsequently consolidated into binding international treaties that include both civil and political rights ${ }^{24}$ and economic, social and cultural rights ${ }^{25}$. They are also the beneficiaries of specific measures designed to protect them in light of their particular vulnerabilities ${ }^{26}$.

The hazardous journeys and miserable detention experiences described above of adolescents swept up in the Arab Spring suggest that, over half a century after Arendt described her pessimistic outlook, the access to fundamental rights protection for young people who lack a government they can call their own remains elusive. Many young people on the move decide to embark on international travel to secure rights they lack at home, rights to adequate shelter, health care and food, an education, the means to earn a living. Some do indeed manage to secure these rights through family reunion, asylum, and other mechanisms for migrating legally. In addition to these legal child migrants, there are children who start their journeys irregularly, using the services of smugglers or false documents or surreptitious means of border crossing, but who then acquire lawful status post migration, through changes in domestic law (e.g. amnesty), changes in their personal situation (e.g. marriage), changes in their legal position (e.g. successful application for compassionate or humanitarian leave), or changes in their nationality through international treaties (e.g. the redrawing of State boundaries) - the process of joining the "state people" that Arendt described (Arendt, 1961: 270).

24 UN General Assembly (1966) International Covenant on Civil and Political Rights (ICCPR), December 16, United Nations, Treaty Series, 999, p. 171.

25 UN General Assembly (1966) International Covenant on Economic, Social and Cultural Rights (ICESCR), December 16, United Nations, Treaty Series, 993, p. 3.

26 These specific instruments include international human rights treaties such as the 1989 Convention on the Rights of the Child which consolidates all previous treaties as they impinge on the rights of children and the 1990 Convention on the Rights of Migrant Workers and their Families. 


\section{Is Irregular Status Synonymous with Rightlessness?}

A significant proportion of children on the move are not so fortunate. Their access to a legal status during and post migration is at best uncertain. Many fall into the precarious position of being unprotected for varying lengths of time, moving in and out of legal status depending on their circumstances. Despite starting off their journey like the adolescents just referred to who transition to a safe immigration category, these young migrants are unable to switch from irregular to legal status, for lack of opportunity or know-how or both. Or they may begin their journeys or residences with a legal status, but find their status changed for the worse with the passage of time. A teenager entering as a lawful visitor invited by relatives living abroad may prolong the visit and end up as an overstaying unpaid domestic worker; a young asylum seeker may be unable to provide adequate evidence to support the claim for refugee status but elect to stay on clandestinely rather than risk persecution by returning; a student may lose that legal status by working without employment authorization.

Irregular or undocumented status, then, may not be a fixed category which defines a migrant's interactions with the State for all time, but rather a varying condition through which a migrant moves at different stages of his or her personal journey. It follows, as Sigona and Hughes rightly note "the definition of who is an irregular migrant is only apparently unproblematic. There is no single category of irregular migrant but differing modes of irregular status resulting from the increasing scope and complexity of international migration. The partition of migrants into two mutually exclusive and jointly exhaustive parts either 'legal' or 'illegal' - dominant in political and public discourse is neither clear in practice, nor conforms to migrants' own experiences and conceptions of their status" (Sigona and Hughes, 2012: 6).

Irregular migration status, especially over long periods of time, brings with it a serious risk of rightlessness for children and adolescents, despite their entitlement to quite extensive human rights protections by virtue of their status as minors codified in both international and domestic law. A critical problem is that adequate mechanisms for the delivery of supervision, accountability and the tools (legal and social) to insist on appropriate treatment, even for the most basic human needs, do not exist. The Women's Refugee Commission report on migrant children in U.S. detention illustrates a point that applies much more broadly: "Nutrition provided to children during their time in border patrol stations is not appropriate for children's physical condition or cultural norms... One seventeen-year-old girl reported being held in a Border Patrol station for an entire day with no food. Another child reported being held for an entire day with no water. A seventeen-year-old boy said he was held for three days and only received juice and one apple" ${ }^{27}$. This rightlessness reflects profound protection lacunae and a continuing social indifference to serious deficits in the material and psychological wellbeing of young migrants.

Further, the tenuous status of these children's right to have rights is stark, with extreme situations catapulting this population beyond the scope of

27 Women's Refugee Commission (2009) Halfway Home: Unaccompanied Children in Immigration Custody, New York, Women's Refugee Commission, 10. 
domestic accountability or international oversight of monitoring bodies. Living in zones of exemption, children in detention often experience indeterminacy and isolation (Bhabha, 2009: 430), as well as arbitrary processes that are expressive of Giorgio Agamben's provocative analogy (Bhabha, 2009: 431). Comparing the treatment of refugees in camps to the paradoxical experiment of the concentration camp, Agamben conceives both junctures as "structures in which the state of exception -the possibility of deciding on which founds sovereign poweris realized normally" (Agamben, 1998: 169-170). Lacking fundamental social protections and entitlements - whether seeking asylum in a U.S. "secure facility" (Bhabha and Schmidt, 2006: 88) or attempting escape from child immigration detention in Spain ${ }^{28}$ - children on the move are often subject to arbitrary rules, punishment, and unprecedented violence.

Despite their demographic and cultural differences, many child and adolescent migrants share key risk factors. Minority, alienage, separation from carers and in many cases irregular status of one sort or another contribute to a common experience of marginalization and psychological insecurity - "a dynamic constellation" of vulnerabilities vis-à-vis the State (Sigona and Hughes, 2012: viii) with far reaching consequences. Most fundamental, perhaps, is the absence of a regular immigration status, with all the consequential exclusions this entails. Irregular migration status generates vulnerabilities that compound or exacerbate pre-existing rights deficits. Addressing this central risk factor is critical to securing a stable rights based environment.

Many thousands of adolescents have been brought up as irregular migrants in States they consider home. The experience of what some have aptly termed "legal liminality" (Menjivar, 2006: 999-1037) can be all pervasive. As an undocumented young Brazilian reflecting on his years living in the United States put it: "You're a nobody in society" (Cebulko, 2014: 11). A similar sentiment was expressed by a seventeen-year-old Afghan boy living in England: "Only when I have documents can I say that I will be complete" (Sigona and Hughes, 2012:

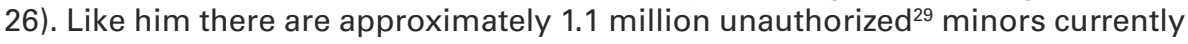
living in the United States (Passel and Taylor, 2010: 1). Many have lived for years with the daily threat of deportation (Kanstroom, 2010) ${ }^{30}$, and all of them experience insecurity vis-à-vis their future. For some, a radical improvement in status may be forthcoming thanks to the courageous, tireless and astute advocacy of young undocumented people themselves - the so-called DREAMers - and the centrality of the Hispanic vote in the forthcoming presidential elections. On June 15, 2012, Janet Napolitano, the Secretary for Homeland Security, announced that, henceforth, undocumented migrants brought to the United

28 Human Rights Watch (HRW) (2009) Nowhere to Turn: State Abuses of Unaccompanied Migrant Children by Spain and Morocco (May 2002), New York, Women's Refugee Commission, 15.

29 Many nouns and adjectives are used to describe individuals who lack a legal migration status: alien, immigrant, migrant, entrant, noncitizen, foreigner, illegal, unlawful, irregular, and undocumented. The term unauthorized migrant will be preferred here where accurate (undocumented may not be, e.g. for those who overstay visas) over more value-laden alternatives.

30 In some US states, notably IIlinois and California, legislation has been passed allowing undocumented students access to school and scholarship programs to finance their education, but in other states, such as Indiana, Alabama and Wisconsin, legislative initiatives to move in the opposite direction have been initiated. 
States before the age of sixteen, with at least five years continuous residence in the United States prior to issuance of her memo, no significant criminal convictions and good school attendance and graduation records, would be protected from deportation and would become eligible to apply for renewable two-year visas provided they were under thirty ${ }^{31}$. For many so-called DREAMers, young people covered by the draft DREAM Act ${ }^{32}$, this change in policy presents an exceedingly welcome and long awaited concession. But for those with criminal convictions, or lack of school attendance records or other disqualifying factors, the problems and insecurity of irregular migration status will continue.

Given the importance of the peer group during adolescence, considerable effort goes into avoiding the loss of status that "being illegal" is thought to entail. For example, a classmate's invitation to join driving lessons can precipitate complicated justifications to conceal one's inability to produce the supporting documents required for registering as a learner driver. This is how one undocumented boy described the conundrum: "And it's kind of annoying not for anybody to know... they're (his friends) always like 'Dude, get your license!' So I kind of make up this whole - like - you know - like image of me like 'I don't want to.'You know, kind of lazy" (Cebulko, 2014: 13). A school trip to Canada can pose an insurmountable problem and reveal the guilty secret of "illegality" to one's classmates. As one adolescent put it: "You are already a minority, and already treated differently. Imagine people finding out you were an illegal minority? None of my friends ever knew. I probably wouldn't have had the ones I had if they had known" (Cebulko, 2014: 12).

This young population dreads all contacts with state authorities, not just with the law enforcement branches, even more than their within status counterparts. An illness can precipitate a crisis about access to public services and the risks of being discovered. Academic success can generate dilemmas about financing college education without eligibility for public support and the forcible truncating of career aspirations (Legomsky, 2011: 217-235). Undocumented status depresses aspirations (Abrego, 2006: 212-231) as young people emerging from school find out about the reality of transitioning to illegality (Gonzales, 2011). For many irregular adolescents who have grown up in the United States, public services established to protect fundamental economic and social rights to health and education are instead perceived as potentially dangerous enforcement agencies capable of precipitating unwanted inquiries into a family's immigration status (Thronson, 2010).

The precarious situation of US based adolescents occurs, mutatis mutandis, in many other immigration destination countries. According to a careful estimate of the situation in the United Kingdom at the end of 2007, there were 155,000 irregular migrant children, of whom 85,000 (over half) were estimated to have been born and to have lived their entire life in the United Kingdom (Sigona and Hughes, 2012: 6). The absence of legal status time and again trumps the nondis-

31 See Department of Homeland Security, Press Release (2012) Secretary Napolitano Announces Deferred Action Process for Young People Who Are Low Enforcement Priorities, June 15.

32 H.R. 1751, $111^{\text {th }}$ Cong. § 4(a) (2009): "special rule for certain long-term residents who entered the United States as children"; S. 3992 111th Cong. § 4 (2010): "cancellation of removal of certain long-term residents who entered the United States as children". 
crimination injunction to protect basic human rights. Within Europe, despite the long-standing vigor of a supranational rights regime and some availability of publicly funded legal and social services, there are serious concerns about access to basic human rights protections for undocumented migrant children and adolescents. According to PICUM, an organization that specializes in issues relating to undocumented populations, "children in an irregular migration situation face numerous barriers to exercising these rights in most European countries. They face high risks of poverty, exploitation, social exclusion, and violence".

The contradiction between international constitutional obligations to protect vulnerable children (described in the following section) and domestic pressures to disqualify all undocumented populations from access to state services manifests itself in different ways across the European continent. In France, the central government has previously refused to provide resources to local councils charged with implementing child protection services for unaccompanied migrant children, forcing affected municipalities to initiate legal proceedings to recover the costs they have incurred in fulfilling their statutory responsibilities ${ }^{33}$. While a recent memorandum from the Ministry of Justice has set up a common procedure wherein the central State finances the first five days of reception considered as "evaluation process" - a number of Departments still refuse care to newly arrived unaccompanied children. In Germany, the opposite process has taken place: although all children, including undocumented children, have a constitutionally guaranteed right to education, this right has, until very recently ${ }^{34}$ been nullified by public officials' duty to report the presence of all undocumented individuals (including children) to the immigration authorities ${ }^{35}$.

In the Netherlands, challenges to government child protection violations have been necessary: state officials refusing child support to undocumented parents only reversed their decision when an appeals Tribunal ruled that this constituted a violation of the local authority's duty of care towards the children ${ }^{36}$. UNICEF investigated the circumstances of unaccompanied migrant adolescents in the United Kingdom and concluded that thousands lived outside any system of care or protection: the report concluded that "the numbers of unaccompanied or separated migrant children who are not known to the authorities could be in the thousands..., likely...more numerous than those... known to the authorities and... seeking asylum". The report quotes an NGO worker concerned about a case that illustrates this point: "We had a child who ended up becoming completely destitute at one of our projects. He had been living with a guy who he said was his Uncle, who had then gone off to Pakistan for six months and left him in the house on his own. He had no food, no money, he didn't even have a coat, actually, and it was the middle of winter" (Brownlees and Finch, 2010: 23).

33 France Terre d'Asile (2011) Mineurs isolés étrangers: le devoir impérieux de protéger, 26 juillet.

34 PICUM Quarterly Newsletter, Aug.-Nov. 2011, 17.

35 Rank Martin (2011) Schulen müssen nicht mehr petzen, TAZ, July 8, cited in PICUM Bulletin, Aug. 29, 2011.

36 PICUM Bulletin, Sep. 12, 2011. 
By default or design, the European Union, the region with the most advanced human rights enforcement mechanisms to date, is failing to consistently protect the basic entitlements of a significant section of children growing up within its jurisdiction simply because they are considered outsiders, children without a state to call their own. It is not just migrant adolescents from outside the European Union who experience pervasive rightlessness. Thousands of migrant Roma adolescents living and working on the streets of Europe's cities do not "belong" within the societies they live in either. Many of these young people qualify for EU citizenship (Cahn and Guild, 2010) and yet documentary and other obstacles prevent them from proving this, ${ }^{37}$ or qualifying for basic services such as school and health care. So they are in no better position vis-à-vis state protection than undocumented noncitizen children. Many live confined to segregated "nomad camps" ${ }^{38}$; often these adolescents lack an effective legal identity because of birth registration or other bureaucratic failures. These young people therefore never make it to secondary school or to the formal employment market.

\section{Whose Best Interests?}

The centrality of the principle of "the best interests of the child" enshrined in the Convention on the Rights of the Child is not disputed, but its application to migrant adolescents is contested. Two issues in particular complicate the enforcement of adolescent migrant rights in relation to the principle: the role of family unity and the appropriate evaluation of access to employment opportunities in the assessment of the best interest of the adolescent migrant.

The right to respect for private and family life, enshrined in many human rights conventions ${ }^{39}$, is critical for children. Not only is the family widely considered the fundamental unit for rearing and nurturing minors, but its absence is a known risk factor precipitating a range of vulnerabilities, from physical risks to psychological and social disadvantages (Shonkoff and Meisels, 2000; Siddiqi, Irwin et al., 2007; UNICEF, 2008) ${ }^{40}$. However, the role that families play changes as children mature: infants, toddlers and young children depend on their parents, for basic survival, for nurturing, for a sense of well-being and self confidence. For older children the balance of dependence changes, particularly in families facing severe hardships - HIV/AIDS infection, displacement by

\section{Ibid., 7.}

38 A dramatic case in point is the situation of children of Serbian asylum seekers in the EU, many of them born in EU countries, but deported in their thousands to Serbia, despite not speaking the language, and becoming destitute and homeless and dropping out of school as a result. See Amnesty International (2010) Not Welcome Anywhere: Stop the Forcible Return of Roma to Kosovo, London, Amnesty International, 64 p.; Human Rights Watch (2006) Croatia: A Decade of Disappointment - Continuing Obstacles to the Reintegration of Serb Returnees, New York, HRW, 41 p.; and Group 484 (2008) Palilula Our Home: Results on Research on Returnees from Western Europe, Belgrade, Group 484, $16 \mathrm{p}$.

39 See UDHR, Arts. 12 and 16; CRC, Arts. 5, 9, 10, 16, 22 and 37; European Convention on Human Rights, Arts. 8 and 12; American Convention on Human Rights, Arts. 11 and 17; African Charter, Art. 18; ICCPR, Arts. 17 and 23; ICESCR, Art. 10.

40 See also CRC Committee (2006) General Comment No. 7: Implementing Child Rights in Early Childhood, CRC/C/GC/7/Rev.1, Sep. 20. 
conflict, destitution through economic crisis, unemployment, illness or familial conflict. These are the sorts of families from which many independent adolescent migrants come, families fractured by crisis or calamity, by unmet need and other forms of acute distress ${ }^{41}$. What role should family unity play in the assessment of their best interests? Migrant adolescents and those representing them challenge the blanket assumption that it should always be THE principal consideration driving decision-making. They point out that on occasion families can be sources of oppression, not protection; for adolescents leaving abusive or incompetent parents, separation might enhance the chances of securing basic rights. Decision making, to be rights respecting and compliant with the obligations set out in binding international law, must be holistic and integrated. As UNICEF and the UN office of the High Commissioner for Human Rights note in their useful report on the judicial implementation of Article 3 of the $\mathrm{CRC}$, the best interests principle "is not a mere resonance box of the more substantive provisions of the CRC" (UNICEF and OHCHR, 2012: 12).

A second issue which differentiates the task of assessing best interest for adolescents from the same assessment applied to younger children is the relative importance of income generating opportunities. While human rights instruments and discourse emphasize the importance of educational goals, not only the non negotiability of the right to primary education but also the centrality of secondary and tertiary education to the realization of rights ${ }^{42}$, most migrant adolescents aspire to employment opportunities as a precondition not a sequel to post primary education. The luxury of postponing income generating activities until late adolescence or beyond eludes them. Official government decisionmaking bodies do not take this approach. Rather adolescent employment, invariably unauthorized and typically "informal" 43 , is considered a factor justifying exclusion rather than an element relevant to a best interest assessment. As Touzenis has rightly noted, children's right to participate in decision making affecting their best interests and the obligation to consider those interests in a

41 As the NEF Action for Children points out, economic pressures, poor housing and other living circumstances, including insecure immigration status, are closely associated with high levels of family stress and less effective parenting skills. See New Economics Foundation (2009) Backing the Future: Why Investing in Children is Good for Us All, London, NEF, 12.

42 See CRC, Art. 28(c); ICESCR, Art. 13(b) and (c); and UN Committee on Economic, Social and Cultural Rights (1999) General Comment No. 13: The Right to Education (Art. 13 of the Covenant), E/C.12/1999/10, Dec. 8; UN Educational, Scientific and Cultural Organisation (UNESCO) (1960) Convention Against Discrimination in Education, 429 UNTS 93, entered into force May 22, 1962, Dec. 14, Art. 4. See also UNICEF (2011) The State of the World's Children 2011: Adolescence - An Age of Opportunity, New York, UNICEF, 138 p.; and The World Bank Group (2002) Constructing Knowledge Societies: New Challenges for Tertiary Education, Washington DC, The World Bank, 204 p.

43 Compare Bernhardt Annette (2008) Research on Informal Work in the U.S., background memo prepared for the WIEGO Workshop on Informal Employment in Developed Countries, Harvard University, Oct. 31-Nov. 1, 10 p. (defining the spectrum between formal and informal work as "[t]he extent to which work is being performed under conditions that either evade or outright violate employment and labor laws, and potentially, normative standards of working conditions. The extent to which we include normative standards in this definition is one of the key conceptual challenges [...]"), with Seventeenth International Conference of Labour Statisticians (2003) Guidelines Concerning a Statistical Definition of Informal Employment, Geneva, International Labour Organization, 4 p. (defining "informal employment" and "formal/informal employment sector"). 
holistic way imply that "access to work" may be a relevant and important factor: "It is especially important to keep in mind that return and family reunification/ placement in an institution without access to work will not always be in the best interests of the child, even if traditional perceptions of what is 'good' and 'bad' for children may lead to this belief" (Farrugia and Touzenis, 2010: 25).

These two issues are often intertwined in the life of adolescent migrants. Family pressures induce urgent income needs, whether because relatives have failed to support the adolescent or because the adolescent himself or herself is relied on to generate resources for the family. In either case, an assessment of the best interests of the minor which prioritizes, as official approaches have tended to, family unity and educational access over the considerations just outlined, may be flawed (Rozzi, forthcoming). In the words of seventeen-year-old Omar, an unaccompanied Moroccan child migrant in Italy: “Your mother doesn't need to say: 'Send the money'. You know from the beginning that they need it. When you call them, and they tell you about their troubles, the loans, the lack of this and that... you know perfectly well what you have to do..." (Vacchiano, 2010: 120). The child/adolescent/adult transition among migrant youth may be quite differently sequenced from the more familiar western pattern. Irregular migration status and the difficulty of accessing appropriate State services compound the "endogenous" vulnerability of migrant adolescents ${ }^{44}$.

The complex competing desires of adolescent migrants complicate the process of protecting their right to have rights. At present there is a lacuna in addressing this issue competently. Unlike younger children, whose need for nurturing, protection, education, health care and guidance can be determined by competent (even if unfamiliar) adults, adolescents may have the maturity to contribute critical insights to the assessment of what would constitute a valid best interests decision. In this context, co-production of decisions engaging adolescent participation may be a more effective and rights enhancing technique for determining cases ${ }^{45}$ than imposition of a one dimensional "family unity" removal strategy. Acknowledgement of adolescents' own agency and the substitution of holistic and individually tailored decision-making strategies introduce indeterminacy and complexity into decision-making. But the cost of such strategies however can be justified over time. Placing unaccompanied adolescent migrants in child care facilities alongside domestic children temporarily removes them from informal street living situations, but fails to generate viable life choices in the medium and long term. By contrast, carefully constructed individual strategies for realizing an adolescent migrant's journey aspirations, through appropriate educational and skill development opportunities may have enduring positive consequences which translate into public sector savings within months. These strategies are not in evidence at present. Standard forms of child care insti-

44 Migrant adolescents whose asylum applications are rejected but who cannot return to their home countries exemplify this situation. In Norway, approximately 400 adolescents currently lack protection or access to health care or education, because they have no legal status and no viable strategies for enforcing their basic rights. Norway International Network (2011) Effort Grows to Revive "Nansenpass", Oct. 10, cited in PICUM Quarterly Newsletter, Aug.-Nov. 2011.

45 Action for Children (2009) Backing the Future: Why Investing in Children is Good for Us All, London, Action for Children, p. 42, for a discussion of "co-production" decision making strategies. 
tutionalization, or unacceptable forms of "secure accommodation" amounting to detention continue to be pervasive responses to the presence of independent adolescent migrants. In the United Kingdom, for example, unaccompanied or separated asylum seeking children "are now thought to represent around $10 \%$ of all children in care" (Brownlees and Finch, 2010: 8). In the United States, 7,211 migrant adolescents are placed in secure facilities annually ${ }^{46}$.

The factors just touched on - problematic familial ties, social marginalization, financial destitution and the urgent need for income generating opportunities precipitate a search for the self-realization that was elusive or impossible in the home context. This search frequently includes risk-taking behavior, driven by the dual imperatives, as one scholar perceptively notes, of "having fun" and "earning money" (Mai, 2010: 72). Mainstream opportunities in the formal economy, in higher education, in salubrious neighborhoods, are generally closed off by discrimination, irregular status and lack of the necessary skill sets (Suarez-Orozco et al., 2011). So the avenues available to adolescent migrants for realizing their goals are predominantly exploitative and unremunerative, antisocial, even self-harming ${ }^{47}$ : begging, stealing, drug selling and prostitution. Mai provides a compelling description of this "very utopian migratory project, often based on an idealization of the West as a place where 'everything is possible'" to the consumption of western television depicting an Eldorado of plenty and permissiveness. "The clash between the adolescent utopian fantasy and the dynamics of social exclusion faced at home and after arrival" in the destination State generates, in Mai's view, "the search for new rituals accommodating the passage between adolescence and adulthood; ... in this context, 'making money' emerges as a key discourse and priority for independent young migrants" (Mai, 2010: 72-73).

But State responses to these choices have tended to be punitive and infantilizing, impeding rather than facilitating these young people's access to education, skill training and income generation.

\section{Child Rights Violations at Points of Entry by Border Officials}

Many leaders of countries experiencing high levels of irregular migration openly voice their opposition to protections for young migrants, even if they are unaccompanied and unprotected. According to a former premier of the Canary Islands, Adan Martin Menis, Moroccan migrant children arriving alone on Spanish territory should be treated like adults, detained or returned to their country of origin (Fekete, 2007: 14). In nearby Italy, the authorities have adopted

46 “ORR placed 7,211 unaccompanied alien children (UAC) in its various housing facilities during FY 2008, a decrease of $12 \%$ from FY 2007. These averaged approximately 1,220 children in care at any point in time" (Office of Refugee Resettlement, US Department of Health and Human Services (2011) Report to Congress FY 2008, Washington DC, Apr. 20, iv).

47This qualification references the discussion about choice and agency among adolescents facing severe structural constraints on their access to livelihood and basic resources. Labeling these forms of income generating activity as "self harming" obscures the structural forces blocking less dangerous choices (O'Connell Davidson, 2006). 
the same approach: on the island of Lampedusa, a destination of much cross Mediterranean migration, rights protection for unaccompanied adolescent migrants is minimal: "Hundreds of children of all ages are detained in inadequate and overcrowded infrastructures in breach of national and international law. They lack medicines, children products and care. Some have already been victims of violence during the increasingly frequent riots between newly arrived migrants and police in the centres" ${ }^{48}$.

The actions of border control officials often mirror the opinions of some of the most rights averse public spokespersons. The daily encounter with sizeable numbers of would-be entrants combined with an institutional ideology that promotes border security and immigration control tends to generate a skeptical, even hostile attitude to many border crossers, particularly those who are indigent and lacking in legal competence and education.

The practice of UK border officials towards adolescent migrants illustrates this implicit rejection of a minimum threshold of rights. This is not a marginal problem. In 2004, as many as $43 \%$ of those applying for asylum as unaccompanied or separated children had their cases "age disputed". A failure to accord children the benefit of the doubt when their age is disputed ${ }^{49}$, pending a final determination of the issue. While forensic age evidence was being examined, they were treated as adults, detained in harsh conditions, conditions so unsuitable for minors that on January 26, 2007, British Home Secretary Jack Reid admitted publicly that the government had been operating an unlawful policy towards child asylum seekers ${ }^{50}$.

A year and a half after the British Home Secretary criticized his government's child migrant detention practices, the Children's Commissioner for England visited Yarl's Wood Immigration Removal Centre, a notorious detention centre equipped with facilities to detain up to 2,000 migrant children each year prior to deportation or removal from the United Kingdom. The visit confirmed that, contrary to government policy and the requirements of the Convention on the Rights of the Child, detention was not being used as a "last resort measure" or for the "shortest length of time possible"51. Even children who required hospitalization during the period of detention had twenty-four-hour police surveillance in the hospital. The Children's Commissioner reported that this intrusive presence had led to a suicide attempt by one teenager; in another case, he observed "four officers around the bedside of a thirteen year-old girl"52. In May 2010, the

48 Gatti Fabrizio (2011) Lampedusa, la prigione dei bambini, L'Espresso, Sep. 9, cited in PICUM Quarterly Newsletter, Aug.-Nov. 2011.

49 This is the approach recommended by UNHCR, the CRC Committee and other experts. See UNHCR (1992) Handbook on Procedures and Criteria for Determining Refugee Status under the 1951 Convention and the 1967 Protocol relating to the Status of Refugees, U.N. Doc. HCR/IP/4/Eng/REV.1, Geneva, UNHCR, para. 196; and CRC Committee (2005) General Comment NO. 6, CRC, para. 39. For a full discussion, see Smith Terry and Brownlees Laura (2011) Age Assessment Practices: A Literature Review \& Annotated Bibliography, New York, UNICEF, 78 p.

50 BBC News (2007) Asylum Seekers Policy "Unlawful", Jan. 26.

51 See Convention on the Rights of the Child (1989) Art. 37, Nov. 20, 1577 U.N.T.S. 3.

52 Children's Commissioner for England (2009) The Arrest and Detention of Children Subject to Immigration Control: A Report Following the Children's Commissioner for England's Visit to the Yarl's Wood Immigration Removal Centre, London, 11 Million, 32 p. 
UK government announced that Yarl's Wood would not long be used to detain children ${ }^{53}$. It eventually paid $\mathrm{f} 2$ million to child asylum seekers wrongly placed in detention ${ }^{54}$. However, the benefits of this decision are unclear as the UK government reduces the availability of legal aid and with it the ability of young unaccompanied to get legal advice and representation and effectively challenge incorrect age determinations. The UK is not alone in its widespread practice of disputing the age of child asylum seekers. Many other countries, including the Netherlands, Spain, the US and Australia, also regularly rely on unreliable onedimensional physical tests to challenge young unaccompanied migrants' claims to protection (Senovilla Hernández, 2013; SCEP, 2012).

\section{Post Border Child Rights Violations by State Officials}

Some public employees working away from the border but engaged in what Kanstroom has termed "post-entry social control" (Kanstroom, 2010: 225-243) reveal similar attitudes about the needs of unprotected children. Brutality, callous disregard of basic survival needs, including refusal to grant benefits or shelter, are common occurrences. Access to social and economic rights including education and health care is also elusive, their denial part of a deterrent immigration control policy targeted at children and young people. As the Committee on the Rights of the Child noted "the threat of destitution as a deterrent against irregular migration generates acute tensions within host States between immigration laws and human rights protections" ${ }^{55}$.

The acute risks to which this willful official turning away, combined with the fear of detection as an irregular migrant by State officials, can give rise were noted by the European Court of Human Rights in the case of Siliadin v. France. In this case, an unaccompanied child from Togo compelled to carry out housework and child care for fifteen hours a day without holidays, the Court commented: “The applicant was entirely at [her employers'] mercy, since her papers had been confiscated; she had no freedom of movement or free time. In addition, as she had not been sent to school... The applicant could not hope that her situation would improve" ${ }^{\prime 56}$.

Irregular migration status increases the risk of being discounted as a person and subjected to gross rights violations. These include the widespread failure to promptly appoint guardians or legal representatives for unaccompanied minors and the lack of any effective transnational cooperation between guardians that might enable effective family tracing and best interests determinations to be carried out; the absence of any effective or consistent transnational cooperation also impedes timely identification of unaccompanied child migrants, a

53 BBC News (2010) Migrant Children Detention to End, Government Says, May 26.

54 PICUM Bulletin, Feb. 2012.

55 Sylvia da Lomba, quoted in Cholewinski Ryszard (2005) Study on Obstacles to Effective Access of Irregular Migrants to Minimum Social Rights, Strasbourg, Council of Europe Publishing, p. 17.

56 European Court of Human Rights (2005) Affaire Siliadin v. France, 73316/01, Arrêt, Strasbourg, 26 July. 
critical first step in the protection process required of States ${ }^{57}$. Because of its complexity it is a task ill suited to rushed inquiry at the border by immigration control officials lacking specialized training. It requires a form of constructive and protective transnational collaboration which is not in evidence. Consider this case:

“D., an Egyptian, told police he was sixteen years old when he first arrived in Italy; he was disbelieved, subjected to a radiological examination of the wrist bone which determined that he was not a minor and, in light of the bilateral agreement between Italy and Egypt, he was repatriated as irregular Egyptian national. D. did not receive a medical certificate or legal assistance and so was unable to appeal the age assessment, avail himself of the two year margin of error and the benefit of the doubt considered appropriate in age disputed cases, and legally challenge the repatriation. There was no systematic call for documentation from relevant consulates, or onward referral for a more thorough assessment. A year later D. migrated with his identity card and on this occasion he was accepted as a minor. The identity card could have been obtained during the first investigation if the Italian authorities had set in motion appropriate special assistance and protection procedures, contacted their Egyptian counterparts. This would have avoided a medically unnecessary Xray and an unjustified return"58.

The absence of automatic access to effective guardianship and legal representation for unaccompanied child and adolescent migrants neutralizes their legal entitlement to special treatment and may effectively obliterate social acknowledgment of their rights. It compounds the complex identification challenges that arise when unaccompanied child migrants come into contact with the authorities. Complexity in fact inheres in the process and the grave protection lacunae I have outlined militate against the careful balancing and assessment that child migrant cases require. Rather the process is more often than not haphazard, even chaotic. No consensus exists on how to balance a welfare driven notion of "the best interests of the child" with an adolescent agency driven notion of "autonomy and independence" with the child's existing or potential vulnerability. Indeed, as Sigona and Hughes point out, undocumented child migrants often do not exist as bureaucratic subjects of concern to State entities in their own right. Rather they encounter public services, haphazardly, through a range of "proxy routes", as children of domestic violence victims or failed asylum seekers, or because of "policy rationales" which relate to their circumstances (addressing poverty among street children, reducing infant mortality) (Sigona and Hughes, 2012: 37). This haphazard approach is ripe for change. Projects enhancing skill training and on the job learning and employment opportunity are desperately needed as an urgent priority. Strengthening transnational communication between those who provide support for children in origin and destination states is also imperative.

For migrant youth in Italy for example, between 2006 and 2010, 42\% of accommodated minors have been reported to have left first reception facilities without authorization (Giovannetti, 2012: 82). The "protection" being offered does not cater to the adolescents' needs and wishes, perhaps because it is

57 Save the Children, Brussels EU office, private communication on file with the author. 58 Save the Children, Brussels EU office, private communication on file with the author. 
infantilizing, non-income generating and patronizing. Some State authorities have resorted to locked shelters to prevent the escape of unauthorized young migrants. This detention is also justified by a concern to protect the minors from traffickers or other sources of exploitation. Detention for protection is a suspect approach. But those such as the Italian and Spanish authorities, who do not detain unauthorized child migrants, acknowledge that a best interest calculation might justify more stringent supervision measures as large proportions of at risk children, many suspected to have been trafficked, disappear from State provision within days of being placed ${ }^{59}$.

Mai argues that standard approaches to adolescent migrants, which highlight the fact of separation from parents and deviance ("errance") unhelpfully pathologize the adolescents' behavior rather than supporting and strengthening their capacity for independent agency (Mai, 2010: 76). As a result, to use Ngai's phrase, many constitute an imported "proletariat outside the polity" (Ngai, 2005: 13). This is an inevitable consequence of the lack of better options back home. Changing the drivers of unsafe migration from areas where children are susceptible to this, is a fundamental building block of a rights respecting international system. But this requires a range of social and economic development interventions implicating transnational cooperation that are very far away.

\section{Conclusion}

For now, then, turning the lacunae just described into enabling support structures through an integrated and holistic incorporation of the substance of human rights protections applicable is the most urgent imperative. We should not be parties to occurrences such as this one recently noted by a child rights NGO in Italy:

“A., a Romanian child who only spoke Italian, was returned from Italy to Romania after having been abandoned in Italy by his mother and forced, with the use of violence, to beg on the streets of Rome by his grandmother. He was found in desperate conditions by law

enforcement authorities and was given to a foster family in Italy for temporary care. In application of the readmission agreement between Italy and Romania for the repatriation of unaccompanied minors, A. was deported to Romania, despite the contrary opinion of the public magistrate and of an NGO instructed by the Court to conduct a physical and psychological report on the child. The child ended up in the care of his family even though they had been denied all parental rights in Italy"60.

Despite good norms on the books and an increasingly vibrant and well organized advocacy movement, consistent and high quality care and secured human rights protections for unaccompanied child migrants remains elusive. But progress is visible and suggests the possibility of further improvements. International bodies are discussing the issue of children on the move with more focus than previously, some States are closing child detention facilities and a

59 Ireland has faced a similar problem. Over the last seven years, 388 children placed in the care of the Irish authorities as suspected victims of trafficking have gone missing and have never been traced. See Kennedy Stanislaus Sr. (2008) Who cares about the disappeared children?, Irish Times, May 23.

60 Field notes from Save the Children unpublished report, on file with the author. 
few governments have apologized, paid damages for rights violations and even changed their procedures to improve child protection access for children and adolescent migrants. But much more remains to be achieved. The scandal of continued removal, incarceration and basic rights denial to tens of thousands of children and young people who deserve much better treatment from the world's richest States implicates all of us.

\section{References}

Abrego Leisy J. (2006) I Can't Go to College Because I Don't Have Papers: Incorporation Patterns of Undocumented Latino Youth, Latino Studies, 4, pp. 212-231.

Agamben Giorgio (1998) Homo Sacer: Sovereign Power and Bare Life, Stanford, Stanford University Press, $199 \mathrm{p}$.

Arendt Hannah (1961) The Origins of Totalitarianism, Ohio, The World Publishing Company, $270 \mathrm{p}$.

Betts Alexander (2006) Towards a Mediterranean Solution? Implications for the Region of Origin, International Journal of Refugee Law, 18 (3-4), pp. 652-676.

Bhabha Jacqueline (2009) Arendt's Children: DoToday's Migrant Children Have a Right to Have Rights?, Human Rights Quarterly,13, pp. 410-451.

Bhabha Jacqueline and Schmidt Susan (2006) Seeking Asylum Alone: Unaccompanied and Separated Children and Refugee Protection in the U.S., Cambridge MA, University Committee on Human Rights Studies, Harvard University, $216 \mathrm{p}$.

Brownlees Laura and Finch Nadine (2010) Levelling the playing field: A UNICEF UK report into provision of services to unaccompanied or separated migrant children in three local authority areas in England, London, UNICEF, 142 p.

Butler Judith and Chakravorty Spivak Gayatri (2007) Who Sings the NationState, Calcutta, New York, Oxford, Seagull Books, pp. 62-66.

Cahn Claude and Guild Elspeth (2010) Recent Migration of Roma in Europe, OSCE, High Commissioner on National Minorities, $91 \mathrm{p}$.

Cebulko Kara (2014) Documented, undocumented, and liminally legal: Legal Status During theTransition to Adulthood for 1.5-Generation Brazilian Immigrants, The Sociological Quarterly, 55, pp. 143-167.

Farrugia Ruth and Touzenis Kristina (2010) The international protection of unaccompanied and separated migrant and asylum-seeking children in Europe, in Daniel Senovilla Hernández, Jyothi Kanics and Kristina Touzenis Eds., Migrating Alone: Unaccompanied and Separated Children's Migration to Europe, Paris, UNESCO Publishing, pp. 21-55.

Fekete Liz, They are Children Too: A Study of Europe's Deportation Policies, London, Institute of Race Relations, 69 p.

Giovannetti Monia (2012) I comuni italiani e le politiche di accoglienza dei minori stranieri non accompagnati, in Monia Giovannetti Ed., I minori stranieri non accompagnati in Italia, Roma, IV rapporto ANCl Cittalia, pp. 37-127. 
Gonzales Roberto G. (2011) Learning to be Illegal: Undocumented Youth and Shifting Legal Contexts in the Transition to Adulthood, American Sociological Review, 76 (4), pp. 602-619.

Kanstroom Daniel (2012) Aftermath: Deportation Law and the New American Diaspora, Oxford, Oxford University Press, 304 p.

Kanstroom Daniel (2010) Deportation Nation: Outsiders in American History, Boston, Harvard University Press, 352 p.

Legomsky Stephen (2011) Undocumented Students, College Education, and Life Beyond, in Jacqueline Bhabha Ed., Children Without a State. A Global Human Rights Challenge, Cambridge MA, The MIT Press, pp. 217-235.

Mai Nicola (2010) Marginalized Young (Male) Migrants in the European Union, in Daniel Senovilla Hernández, Jyothi Kanics and Kristina Touzenis Eds., Migrating Alone: Unaccompanied and Separated Children's Migration to Europe, Paris, UNESCO Publishing, pp. 69-89.

Menjivar Cynthia (2006) Liminal Legality: Salvadoran and Guatemalan Immigrants' Lives in the United States, American Journal of Sociology, 111, pp. 999-1037.

Ngai Mae M. (2005) Impossible Subjects: Illegal Aliens and the Making of Modern America, Princeton University Press, 400 p.

O'Connell Davidson Julia (2006) Children in the Global Sex Trade, Cambridge UK, Polity Press, $224 \mathrm{p}$.

Passel Jeffrey S. and Taylor Paul (2010) Unauthorized Immigrants and Their U.S.-Born Children, Washington DC, Pew Hispanic Center, 10 p.

Rozzi Elena (forthcoming) Transitions to Adulthood: Between Socio-cultural Differences and Universal Rights, in Jacqueline Bhabha Ed., Coming of Age: Reframing the Approach to Adolescent Rights, Philadelphia, University of Pennsylvania Press.

SCEP (2012) Position Paper on Age Assessment in the Context of Separated Children in Europe, Separated Children in Europe Programme, 22 p.

Senovilla Hernández Daniel (2013) Unaccompanied Children Lacking Protection in Europe. Final Comparative Report, PUCAFREU (Promoting unaccompanied children's access to fundamental rights in the European Union), MIGRINTER, CNRS, University of Poitiers, 122 p.

Shonkoff Jack P. and Meissels Samuel J. Eds. (2000) The Handbook of Early Child Intervention, New York, Cambridge University Press, 734 p.

Siddiqi Arjumand, Irwin Lori G. and Hertzman Clyde (2007) Total Environment Assessment Model for Early Child Development: Evidence Report for the World Health Organization's Commission on the Social Determinants of Health, Vancouver BC, Human Early Learning Partnership, 112 p.

Sigona Nando and Hughes Vanessa (2012) No way out, no way in. Irregular migrant children and families in the UK, COMPAS, University of Oxford, $46 \mathrm{p}$.

Suárez-Orozco Carola, Yoshikawa Hirokazu,Teranishi RobertT. and Suárez-Orozco Marcelo M. (2011) Growing Up in the Shadows: The Development Implications of Unauthorized Status, Harvard Education Review, 81 (3), pp. 438-473. 
Thronson David B. (2010)Thinking Small:The Need for Big Changes in Immigration Law's Treatment of Children, UC Davis Journal of Juvenile Law and Policy, 14, pp. 239-262.

UNHCR (United Nations High Commissioner for Refugees) (2007) Refugee Protection and Mixed Migration: A 10-Point Plan of Action, Geneva, UNHCR, 10 p.

UNICEF (2008) The Impact of Parental Deprivation on the Development of Children Left Behind by Moldovan Migrants, New York, UNICEF, 96 p.

UNICEF and Office of the United Nations High Commissioner for Human Rights (2012) Judicial Implementation of Article 3 of the Convention on the Rights of the Child in Europe: The Case of Migrant Children Including Unaccompanied Children, Belgium, UNICEF and OHCHR, $111 \mathrm{p}$.

Vacchiano Francesco (2010) Bash n 'ataq I-walidin ('to save my parents'): Personal and Social Challenges of Moroccan Unaccompanied Children in Italy, in Daniel Senovilla Hernández, Jyothi Kanics and Kristina Touzenis Eds., Migrating Alone: Unaccompanied and Separated Children's Migration to Europe, Paris, UNESCO Publishing, pp. 107-127.

Weber Leanne and Pickering Sharon (2011) Globalization and Borders: Death at the Global Frontier, Basingstoke: Palgrave Macmillan, 264 p.

Yaqub Shahin (2009) Independent Child Migrants in Developing Countries: Unexplored Links in Migration and Development, Innocenti Working Paper No. 2009-01, Florence, UNICEF, 85 p. 


\section{Jacqueline Bhabha}

\section{Moving Children: Lacunae in Contemporary Human Rights Protections for Migrant Children and Adolescents}

This article addresses a contemporary demographic phenomenon, the growing presence of young migrant children and adolescents, and outlines the perils that this population faces. What some experts refer to as an "asylum-migration nexus," or a blurring of legal categories within contemporary migration, this varied and multifaceted flow includes asylum seekers, exploited unaccompanied children, job seekers, education or opportunity seekers, and adolescents seeking family reunion with previously migrated parents - all of them, in one way or another, young people on the move for a better life. This article posits that all young migrants need protection and assistance of one sort or another: Safe accommodation, and protection from exploitation, from the risks of criminalization, from deprivation of food and medical care at a minimum. Though progress is visible, much more remains to be achieved. The scandal of basic rights denial to tens of thousands of children and young people who deserve much better treatment from the world's richest States implicates all of us.

\section{Mineurs en migration : les lacunes des droits de I'homme contemporains en matière de protection des enfants et adolescents migrants}

Cet article aborde un phénomène démographique contemporain, celui de la présence croissante de jeunes enfants et adolescents en situation de migration indépendante, et souligne les dangers auxquels cette population est confrontée. Ce que certains experts appellent un " lien entre asile et migration " ou un mélange des catégories juridiques au sein des migrations contemporaines, constitue un flux varié et multiforme qui inclut des demandeurs d'asile, des mineurs non accompagnés exploités, des demandeurs d'emploi ou d'éducation, ou encore des adolescents à la recherche d'un regroupement familial auprès de parents ayant préalablement migré. Chacun d'entre eux, d'une manière ou d'une autre, est un jeune en mouvement en quête d'une vie meilleure. Cet article part du postulat que tous les jeunes migrants ont besoin de protection et d'assistance : un hébergement sûr, de la nourriture et des soins, ainsi qu'une protection contre l'exploitation et contre les risques de criminalisation. Bien que les progrès à cet égard soient visibles, il reste encore beaucoup à faire. Le scandale du déni des droits fondamentaux de dizaines de milliers d'enfants et de jeunes qui mériteraient un traitement plus humain de la part des pays les plus riches de la planète nous concerne tous. 


\section{... Menores migrantes: las deficiencias de los derechos humanos contemporáneos con respecto a la protección de los niños y adolescentes migrantes}

Este artículo se interesa por un fenómeno demográfico contemporáneo, la creciente presencia de menores y adolescentes migrantes y describe los peligros a los que esta población hace frente. Lo que algunos expertos denominan como el "nexo entre asilo y migración», o una fusión de diferentes categorías legales dentro de las migraciones contemporáneas, constituye un flujo variado y multifacético que incluye a solicitantes de asilo, menores no acompañados explotados, solicitantes de empleo, demandantes de formación u oportunidades, adolescentes que buscan una reunificación familiar con sus padres que habían migrado previamente, etc. Todos ellos son jóvenes en movimiento en busca de una vida mejor. Este artículo plantea que todos los menores migrantes necesitan protección y asistencia de una u otra forma: alojamiento seguro, protección contra la explotación, protección contra el riesgo de delincuencia, asistencia sanitaria, avituallamiento, etc. Aunque el progreso sea visible, queda mucho margen de mejora. El escándalo de la denegación de derechos básicos que afecta a decenas de miles de menores y jóvenes que merecen un tratamiento más humano por parte de los países más ricos del mundo es responsabilidad de todos nosotros. 